COMPETITOR: Jurnal Pendidikan Kepelatihan Olahraga

Volume 13 Number 2 Year 2021

e-ISSN: 2657-0734 \& p-ISSN: 2085-5389

This work is licensed under a Creative Commons Attribution 4.0 International License

\title{
Implementation of Higher Order Thinking Skills In Physical Education Learning In Covid-19 Era: Is It Work?
}

\author{
Rifqi Festiawan ${ }^{1 *}$, Mochammad Fath Khurrohman ${ }^{2}$ \\ ${ }^{1}$ Department of Physical Education, Faculty of Health Science, Jenderal Soedirman University, Central \\ Java, Indonesia \\ ${ }^{1}$ Dr. Soeparno Street, Karangwangkal, North Purwokerto, Banyumas \\ ${ }^{2}$ Department of Physical Education, Postgraduate Program, Yogyakarta State University, Yogyakarta, \\ Indonesia \\ ${ }^{1}$ rifqi.festiawan@unsoed.ac.id, ${ }^{2}$ mochfath.2020@student.uny.ac.id
}

Received: Maret 15, 2021; Reviewed: April 23, 2021; Accepted: May 02, 2021;

Published: June 18, 2021

\begin{abstract}
This study aims to determine how well the implementation of Higher Order Thinking Skills (HOTS) based on Physical Education at Banyumas Regency in 2020. This type of research is a quantitative descriptive study using a survey method. The population in this study were all physical education teachers in Banyumas Regency, totalling 29 teachers, who were taken using the total sampling technique. The data collection technique used a questionnaire. The data analysis technique used percentage descriptive analysis. The results showed that the implementation of Higher Order Thinking Skills (HOTS) based Physical Education at Banyumas Regency in 2020 was in the "very poor" category of 0.00\% (0 teachers), "less" of $51.72 \%$ (15 teachers), " enough "by 48.28\% (14 teachers), "good "by 0.00\% (0 teachers), and "Very good" by $0.00 \%$. From these results, can be concluded that the implementation of Higher Order Thinking Skills (HOTS) based Physical Education at Banyumas Regency in 2020 was less category. This is certainly an evaluation so that the implementation of the 2013 curriculum can be further improved so that learning objectives can be achieved properly.
\end{abstract}

Keywords: Higher Order Thinking Skills; Kurikulum; Physical Education; Learning.

\section{INTRODUCTION}

Implementation of the 2013 Curriculum, which is a reference for the learning process in educational units, according to policy, needs to integrate Strengthening Character Education (PPK). This integration is not an additional or optional program, but a single unit of education and learning for all educational actors in an educational unit(Jailani et al., 2017). Presidential Regulation Number 87 of 2017 concerning Strengthening Character Education (PPK) makes character education an "educational movement under the responsibility of the education unit to strengthen the character of students through harmonization of heart, feeling, thinking, and sports with involvement 
and cooperation. educational units, families, and communities as part of the National Movement for the Mental Revolution. This Presidential Regulation is the initial basis for putting character education back in place as the main soul in the delivery of education in Indonesia, strengthened by the issuance of Permendikbud Number 20 of 2018 concerning Strengthening Character Education in Formal Education Units.

In the 2013 curriculum learning, several paradigm changes have been used by teachers, these changes are intended to adapt to the demands of the times and prepare Indonesian human resources to be ready to compete in the future. Learning with the 2013 curriculum trains students to find out, not only be told about science, emphasizes language skills as a means of communication, carriers of knowledge, and to think logically, systematically, and creatively (Nurcahyo et al., 2021; Wicaksono et al., 2020).

Assessment is carried out by measuring the level of thinking of students from low to high, not just memorizing concepts, measuring student work processes and outcomes, and using student learning portfolios (Abdullah et al., 2015). The implementation of the 2013 curriculum $(\mathrm{K}-13)$ has a consequence that teachers must be more qualified in carrying out learning activities. Why is that? Because K-13 mandates the application of a scientific approach (5M) which includes observing, asking, gathering information, reasoning / associating, and communicating. The government expects students to achieve various competencies by applying higher-order thinking skills (Kamaludin et al., 2020; Ngadiman et al., 2019).

These competencies are critical thinking, creativity and innovation, communication skills, the ability to work together (collaboration), and confidence(Ichsan, Sigit, et al., 2020). The five things conveyed by the government that are the character targets of students are attached to the evaluation system in the national exam and are the skills of the 21 st century (Wechsler et al., 2018).

Students who have low-level thinking skills without higher-order thinking exercises cause the student learning process to not be achieved perfectly (Ichsan et al., 2019). Therefore, an instrument is needed to support students to become accustomed to higherorder thinking. The instrument is a test which in its completion requires higher-order thinking skills or what we are more familiar with is the Higher Order Thinking Skills (HOTS)-based test (Tyas \& Naibaho, 2021). High-order thinking skills demand critical, creative, analytical thinking on information and data in solving problems (Pratama \& Retnawati, 2018). High-level thinking is a type of thinking that tries to explore questions about existing knowledge related to issues that are not clearly defined and do not have 
definite answers (Ichsan, Rahmayanti, et al., 2020). Developing critical thinking requires practice finding patterns, compiling explanations, making hypotheses, making generalizations, and documenting findings with evidence (Widiatsih et al., 2020). This shows that learning that triggers students to think at a higher order requires the use of active student-oriented learning strategies so that students have the opportunity to observe, ask, reason, try, and communicate. This kind of approach fits perfectly with the expectations of the 2013 curriculum (Festiawan, 2015; Yustifar et al., 2021).

The 2013 curriculum is a competency-based curriculum in which the 2013 curriculum uses a scientific approach or so-called scientific approach, namely observing, asking, trying, reasoning, and communicating (Retnawati et al., 2016). The purpose of using the scientific approach model or scientific approach based on the 2013 Curriculum Diktat module is intended to provide understanding to students in recognizing, understanding various materials using a scientific approach, that information can come from anywhere, anytime, not depending on unidirectional information from the teacher. Therefore, the learning conditions that are expected to be created are directed at encouraging students to find out from various sources of observation, not being told (Festiawan, 2020; Gunawan, 2017; Kogoya et al., 2021).

A teacher must have academic qualifications and know the basics of science, one of which is carrying out RPP preparation activities so that in implementing teaching and learning activities the teacher can direct learning activities from beginning to end. This proves that a Physical Education teacher must be able to compile a lesson plan properly and following K13 standards and it will be better if it is Higher Order Thinking Skills (HOTS) oriented (Yuliati \& Lestari, 2018), which is to stimulate students to be more critical and courageous because Higher Order Thinking Skills (HOTS) -oriented teachers will tend to build classes with representations, describe the material every time they teach and build relationships with students with activities that involve mentally trained, so that teaching and learning activities can run well (Festiawan et al., 2019).

This research was conducted in Sleman Regency. Sleman Regency is divided into 4 zones based on the Regulation of the Head of the Sleman Regency Education Office number: 01 of 2018, namely the western, eastern, central, and northern zones. In this study, the object of research is the Banyumas District.

Based on the results of an interview conducted with one of the Physical Education teachers, the teacher has participated in several workshops for the preparation of Learning Implementation Plans, the teacher also always makes and prepares RPP at the 
beginning of the semester. The teacher used the RPP from the MGMP results, but there was also one teacher who compiled part of the lesson plans he made himself. Another problem, related to the implementation of the 2013 curriculum in the field, still finds several obstacles in its implementation. Researchers see that Physical Education teachers still do not understand the 2013 curriculum. This is because teachers feel that they are almost retired so that in teaching they still use the 2006 curriculum teaching method and in understanding the 2013 curriculum only know without practising in the field. Observation during learning, the method used by the teacher has not led to Higher Order Thinking Skills (HOTS) -related learning methods. Interviews with several stated teachers that teachers did not know how to implement Higher Order Thinking Skills (HOTS) during learning.

In practice, teachers are still dominant in teaching (teacher centre). This is in stark contrast to the learning of the modern era of 21 st-century skills, namely students are more active in learning (student centre). For example, in the practice of learning large balls such as basketball, the teacher explains a lot of material so that it consumes lesson hours. The teacher only provides a final assessment of learning carried out through motoric movement practices, the assessment should be carried out thoroughly from the affective and cognitive aspects. This has an impact on students not maximizing practice and feeling bored with Physical Education subjects which should be fun.

\section{METHOD}

\section{Types of research}

This research is a descriptive study, used to describe or describe the data that has been collected as it is (Sugiyono, 2016). The method used in this research is a survey. (Arikunto, 2013)stated that the survey is one of the research approaches that are generally used for extensive data collection. This study will describe the implementation of Higher Order Thinking Skills (HOTS) -based implementation of physical education learning.

\section{Time and Place of Research}

The research site is in Banyumas Regency which consists of 4 districts and 16 schools. This research was conducted in March 2020.

\section{Research Targets / Subjects}

The population is the entire subject of the study, while the sample is a portion of the population(Sugiyono, 2016). The population in this study were 29 physical education 
Implementation of Higher Order Thinking Skills In Physical Education Learning In Covid-19 Era: Is It Work?

teachers in Banyumas Regency. While the sample is determined using a total sampling technique.

\section{Data, Instruments, and Data Collection Techniques}

The instrument or tool used in this study was a closed questionnaire. The closed questionnaire is a questionnaire presented in such a form that the respondent only has to give a checklist $(\sqrt{ })$ in the appropriate column or place, with a direct questionnaire using a multilevel scale(Arikunto, 2013). The stratified scale in this questionnaire uses a modified Likert scale with four answer choices.

The grid for the implementation of Physical Education Learning Based on Higher Order Thinking Skills (HOTS) in Banyumas Regency in 2020 is presented in table 1 as follows:

Table 1.

Instrument Grille

\begin{tabular}{llc}
\hline Factor & Indicator & $\begin{array}{c}\text { Item } \\
\text { Number }\end{array}$ \\
\hline Planning & 1. Observing the KD that will be used in HOTS & 1 \\
& loads & \\
2. Develop indicators based on KKO containing & 2 \\
& HOTS & 3 \\
3. Learning objectives & 4 \\
4. Subject matter & 5 \\
5. Determine supportive learning methods & 6 \\
6. Design learning steps & 7 \\
7. Selecting media & 8 \\
8. Designing the type of assessment & 9 \\
9. Determine the assessment instrument & 10 \\
1. Apperception & 11 \\
2. Warming up & 12,13 \\
3. Observe & 14,15 \\
4. Ask & 16 \\
5. Try & 17,18 \\
6. Associate & 19 \\
7. Accommodating & 20 \\
8. Reasoning & 21 \\
9. Communicate & 22,23 \\
1. Cognitive & 24,25 \\
2. Affective & 26 \\
3. Psychomotor &
\end{tabular}

The data collection technique that will be used is by giving questionnaires to respondents who are the subjects of the study. The mechanisms are as follows: (1) The researcher requests a research permit from the Faculty. (2) Researchers look for data on 
Implementation of Higher Order Thinking Skills In Physical Education Learning In Covid-19 Era: Is It Work?

physical education teachers in Banyumas Regency. (3) Researchers distribute questionnaires to respondents. (4) Then the researcher collects a questionnaire and performs a transcript of the results of filling out the questionnaire. (5) After obtaining research data, the researcher draws conclusions and suggestions.

\section{Data analysis technique}

The data analysis technique in this research is using the percentage descriptive data analysis technique.

$$
\mathrm{P}=\% \frac{F}{N} X 100
$$

\section{Information:}

$M$ : average value (mean)

$X$ : score

$S$ : standard deviation

The determination of the score criteria uses the ideal Norms Reference Assessment (PAN) in table 2 as follows:

Table 2. Valuation Norms

\begin{tabular}{lc}
\hline \multicolumn{1}{c}{ Interval } & Category \\
\hline $\mathrm{Mi}+1.8 \mathrm{Sbi}<\mathrm{X}$ & Very good \\
$\mathrm{Mi}+0.6 \mathrm{Sbi}<\mathrm{X} \leq \mathrm{Mi}+1.8 \mathrm{Sbi}$ & Good \\
$\mathrm{Mi}-0.6 \mathrm{Sbi}<\mathrm{X} \leq \mathrm{Mi}+0.6 \mathrm{Sbi}$ & Enough \\
$\mathrm{Mi}-1.8 \mathrm{Sbi}<\mathrm{X} \leq \mathrm{Mi}-0.6 \mathrm{Sbi}$ & Less \\
$\mathrm{X} \leq \mathrm{Mi}-1.8 \mathrm{Sbi}$ & Very less \\
\hline
\end{tabular}

\section{Information:}

$\mathrm{X}=$ average

$\mathrm{Mi} \quad=1 / 2$ (ideal max score + ideal min score)

Sbi $=1 / 6$ (ideal max score - ideal min score)

Ideal max score = highest score

Ideal min score = lowest score

\section{RESULTS AND DISCUSSION}

\section{Research result}

Table 3.

Descriptive Statistics

\begin{tabular}{lccc}
\hline & Min (\%) & Max (\%) & Mean \pm SD (\%) \\
\hline $\begin{array}{l}\text { The results of research on the } \\
\text { implementation of physical } \\
\text { education learning based on } \\
\text { higher-order thinking skills } \\
\text { (HOTS) }\end{array}$ & 50 & 69 & $60.03 \pm 5.02$ \\
\hline
\end{tabular}


Descriptive statistics on the results of research on the implementation of physical education learning based on higher-order thinking skills (HOTS) in Banyumas district in 2020, the lowest score was 50.00, the highest score was 69.00 , the average was 60.03 , and the standard deviation (SD) was 5.02.

The implementation of Higher Order Thinking Skills (HOTS) -based physical education learning in Banyumas Regency in 2020 can be presented in Figure 1 as follows:

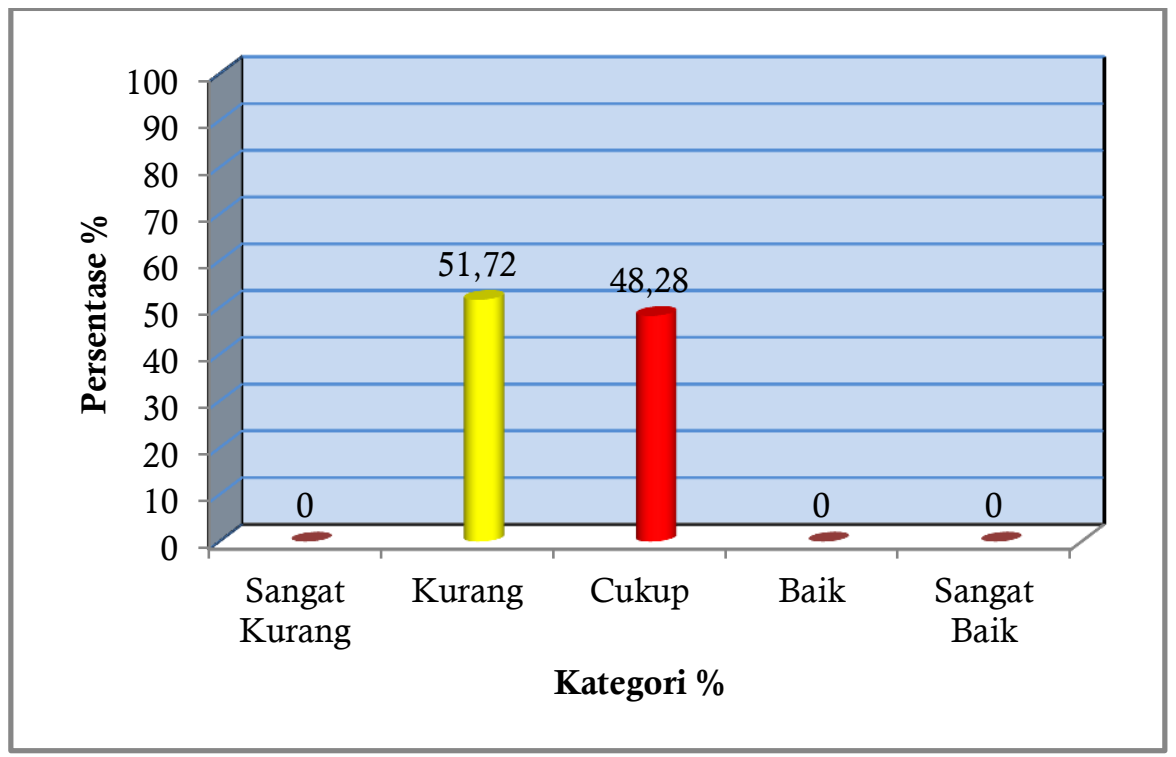

Figure 1.

Bar chart of the implementation of higher-order thinking skills (HOTS) -based physical education learning in Banyumas Regency in 2020

Based on Figure 1 above shows that the implementation of physical education learning based on higher-order thinking skills (HOTS) in Banyumas Regency in 2020 is in the "very poor" category of $0.00 \%$ ( 0 teachers), "lacking" of $51.72 \%$ ( 15 teachers), "enough" by 48.28\% (14 teachers), "good" by $0.00 \%$ (0 teachers), and "very good" by $0.00 \%$ (0 teachers). Based on the average value, which is 60.03 , in the "fair" category.

\section{Planning Factors}

The implementation of higher-order thinking skills (HOTS) based physical education learning in Banyumas Regency in 2020 based on planning factors can be presented in Figure 2 as follows: 


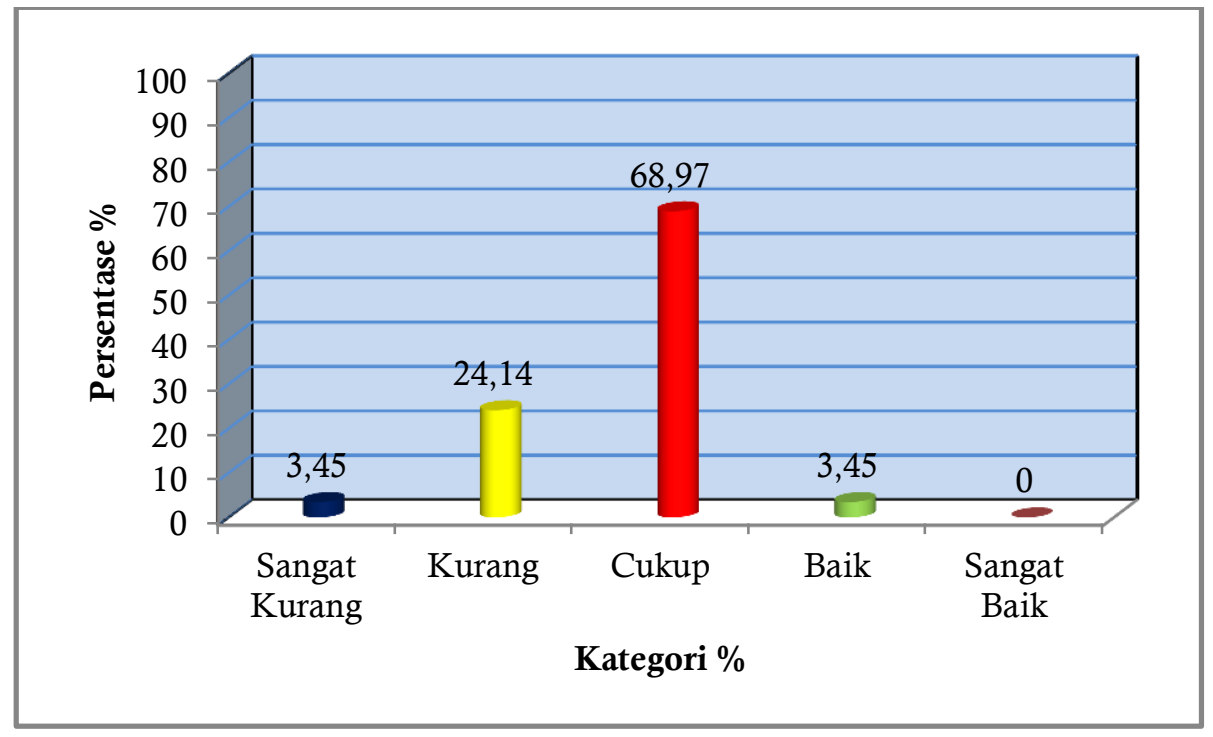

Figure 2.

Bar Charts Based on Planning Factors

\section{Implementation Factors}

The implementation of higher-order thinking skills (HOTS) based physical education learning in Banyumas Regency in 2020 based on the implementation factor can be presented in Figure 3 as follows:

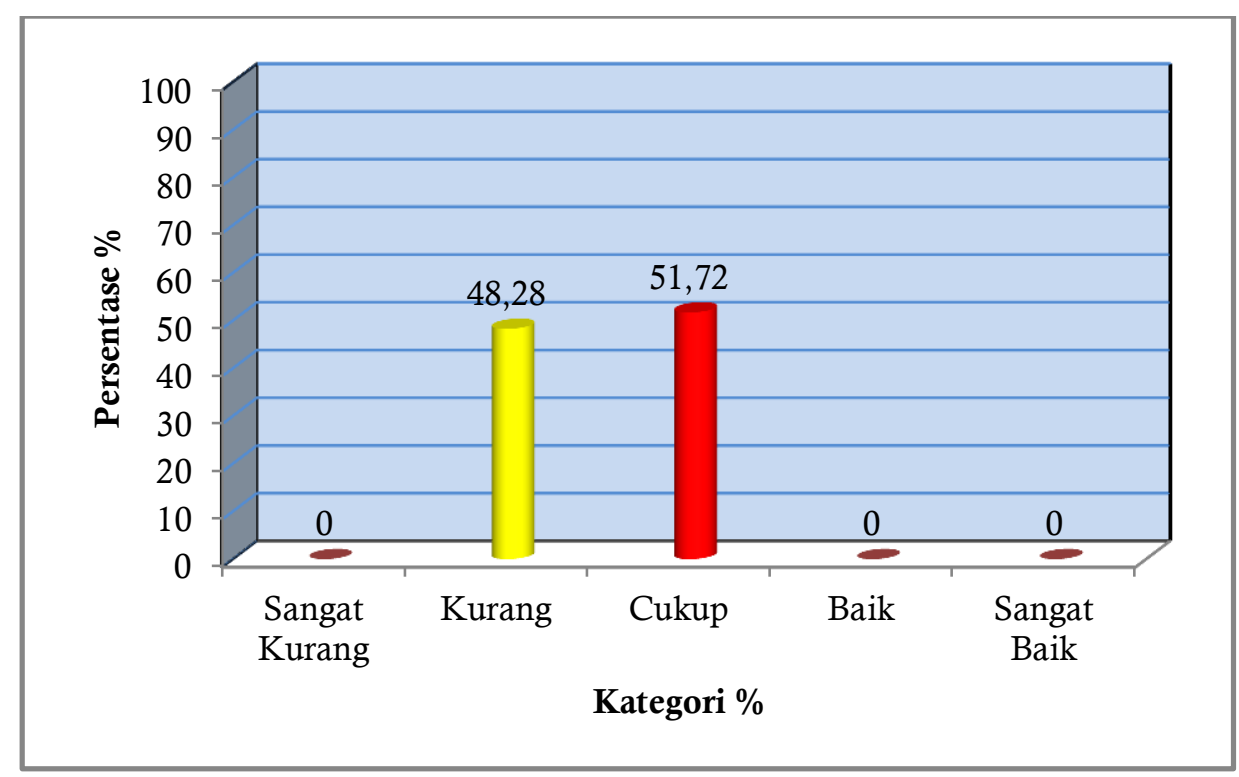

Figure 3.

Bar Charts Based on Implementation Factors

\section{Evaluation Factors}

The implementation of higher-order thinking skills (HOTS) based physical education learning in Banyumas Regency in 2020 based on the evaluation factor can be presented in Figure 4 as follows: 


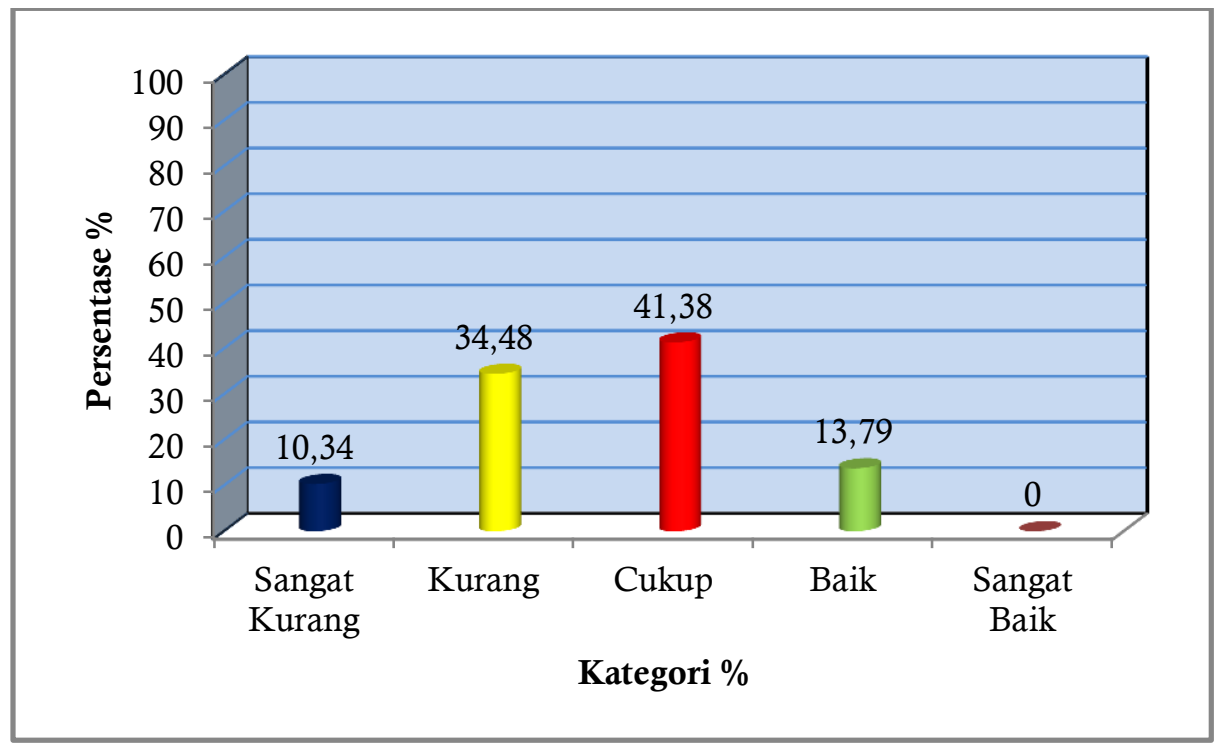

Figure 4.

Bar Charts Based on Evaluation Factors

\section{Discussion}

This study aims to determine the implementation of higher-order thinking skills (HOTS) based physical education learning in Banyumas Regency in 2020, which is expressed by a questionnaire totalling 26 items, divided into three factors, namely planning, implementation, and evaluation factors. Based on the results of the study, the implementation of higher-order thinking skills (HOTS) -based physical education learning in Banyumas Regency in 2020 was in the sufficient category. In detail, there were at most in the deficient category there were 15 teachers or $51.72 \%$, then in the sufficient category, there were 14 teachers or $48.28 \%$. The figure of an educator or teacher is very important to create better education. As mentioned(Kim et al., 2019)that teachers are professional educators with the main task of educating, teaching, guiding, directing, training, assessing, and evaluating students in early childhood education through formal education, primary education and secondary education which require certain competencies.

Based on the results above, it shows that the implementation of physical education learning based on higher-order thinking skills (HOTS) in Banyumas Regency is still not maximally applied during learning. Teachers should be able to change the pattern of learning comprehensively based on higher-order thinking skills and activity-based. The way that can be done to adopt this is by developing learning planning, implementing learning, and authentic assessment based on higher-order thinking skills (HOTS) in each 
lesson. (Widana et al., 2019). However, in practice, the development of planning, implementation and authentic assessment based on higher-order thinking skills (HOTS) is not something easy for teachers to do. Besides, the teacher must master the material and learning strategies, the teacher is also faced with challenges with the environment and the intake of the students they teach.

This refers to the statement that, "Science education worldwide reforms are derived from the constructivist views of teaching and learning. These reforms are explicitly asked teachers to change their teaching strategies by shifting the emphasis from traditional textbook-based and rote learning to exploration and inquiry-based learning situated in real-world phenomena ",(Lin et al., 2019). That is, the reform of educational science around the world comes from a constructivist view of teaching and learning. This reform explicitly calls on teachers to change their teaching strategies by shifting the emphasis from traditional text-based learning and rote learning to exploration and inquiry-based learning that is oriented towards real-world phenomena.

Higher-order thinking skills (HOTS) based learning in the 2013 Curriculum can be done by compiling competency attainments that not only answer at levels C-1 (knowing), C-2 (understanding), and C-3 (applying), but also at the level of C-1 (knowing), C-2 (understanding), and C-3 (applying). C-4 (synthesis / analysis), C-5 (evaluation), and C-6 (creative). Learning to think critically as a characteristic of higher-order thinking skills (HOTS) is not like learning about material directly(Narayanan \& Adithan, 2015). Critical thinking is related to how to solve problems that are related to one another. Critical thinking enables students to discover the truth amidst the events and information that surround them every day(Fuad et al., 2017). Through critical thinking, students will experience a systematic process that enables them to formulate and evaluate their own beliefs and opinions.

Implementation of higher-order thinking skills (HOTS) based physical education learning in Banyumas Regency in 2020 based on planning factors in the "adequate" category. The assessment of higher-order thinking skills (HOTS) comes from learning planning based on higher-order thinking skills (HOTS) with characteristics, one of which is the indicator and learning objectives used, namely dominantly using cognitive level 3 , namely C4-C6. Then from the predetermined goals, learning steps were made that reflected higher-order thinking skills (HOTS) learning. Learning planning must begin with an understanding of the meaning and purpose, as well as mastering the theoretical 
and practical elements contained therein. The ability to make plans is the first step for teachers and prospective teachers,

Learning planning is designed in the form of a syllabus and lesson plan (RPP) which refers to the content standard. Learning planning includes the preparation of learning implementation plans and preparation of media and learning resources, learning assessment tools, and learning scenarios. The preparation of the syllabus and lesson plans is adjusted to the learning approach used.

The implementation of higher-order thinking skills (HOTS) based physical education learning in Banyumas Regency in 2020 is based on the implementation factor in the "sufficient" category. Following the Permendikbud, Learning Implementation (RPP) is a face-to-face learning activity plan for one or more meetings. RPP is developed from the syllabus to direct the learning activities of students to achieve Basic Competence (KD). Every educator in an education unit is obliged to prepare a complete and systematic lesson plan so that learning takes place in an interactive, inspirational, fun, challenging, efficient manner, motivates students to participate actively, and provides sufficient space for initiative, creativity, and independence according to their talents, interests. , and the physical and psychological development of students.

The implementation of higher-order thinking skills (HOTS) based physical education learning in Banyumas Regency in 2020 is based on the evaluation factor in the "sufficient" category. Assessment and evaluation of learning need to be done because, with the results of the assessment, students can find out their strengths and weaknesses in learning so far. Because the benefits of assessment for students are that students can find out how far they have succeeded in following the learning delivered by the teacher(Brevik et al., 2017). According to Permendikbud number 22 of 2016, the assessment of the learning process uses an authentic assessment approach that assesses the readiness of students, the process, and learning outcomes as a whole. The integration of the assessment of the three components will describe the capacity, style, and learning acquisition of students who can produce an instructional effect on the knowledge aspect and the nurturant effect on the attitude aspect. (Van der Kleij et al., 2018). The results of the authentic assessment are used by the teacher to plan remedial learning, enrichment, or counselling services. In addition, the results of the authentic assessment are used as material to improve the learning process following the Education Assessment Standards.

Evaluation of the learning process is carried out during the learning process using the following tools: observation sheets, peer questionnaires, recordings, anecdotal notes, 
Implementation of Higher Order Thinking Skills In Physical Education Learning In Covid-19 Era: Is It Work?

and reflections. Evaluation of learning outcomes is carried out during the learning process and at the end of the lesson unit using methods and tools: oral / action tests, and written tests. The final evaluation results are obtained from a combination of process evaluation and evaluation of learning outcomes.

\section{CONCLUSIONS AND SUGGESTIONS}

Based on the results of data analysis and discussion, it can be concluded that the implementation of physical education learning based on higher-order thinking skills (HOTS) in Banyumas Regency in 2020 is in the "very poor" category of $0.00 \%$ (0 teachers), "lacking" of 51, 72\% (15 teachers), "enough" of 48.28\% (14 teachers), "good" of $0.00 \%$ ( 0 teachers), and "very good" of $0.00 \%$ ( 0 teachers).

\section{REFERENCES}

Abdullah, A. H., Abidin, N. L. Z., \& Ali, M. (2015). Analysis of students' errors in solving Higher Order Thinking Skills (HOTS) problems for the topic of the fraction. Asian Social Science, 11(21), 133-142. https://doi.org/10.5539/ass.v11n21p133

Arikunto, S. (2013). Prosedur Penelitian: Suatu Pendekatan Praktik (Edisi Revisi). In Jakarta: Rineka Cipta. https://doi.org/10.1017/CBO9781107415324.004

Brevik, L. M., Blikstad-Balas, M., \& Engelien, K. L. (2017). Integrating assessment for learning in the teacher education programme at the University of Oslo. Assessment in Education: Principles, Policy and Practice, 24(2), 164-184. https://doi.org/10.1080/0969594X.2016.1239611

Festiawan, R. (2015). Pedagogi Olahraga (Sport Pedagogy). Universitas Jenderal Soedirman, 1-23.

Festiawan, R. (2020). Belajar dan Pendekatan Pembelajaran. 2020, 1-17. https://osf.io/mpng9/download

Festiawan, R., Ngadiman, N., Kusuma, I. J., Nurcahyo, P. J., \& Kusnandar, K. (2019). Pengembangan Model Pembelajaran Pendidikan Jasmani Berbasis Games, Education, and Visualisation (GEV) Untuk Meningkatkan Pengetahuan Kesehatan Reproduksi Remaja. Jendela Olahraga, 4(2), 13-25. https://doi.org/10.26877/jo.v4i2.3678

Fuad, N. M., Zubaidah, S., Mahanal, S., \& Suarsini, E. (2017). Improving junior 
high schools' critical thinking skills based on test three different models of learning. International Journal of Instruction, 10(1), 101-116. https://doi.org/10.12973/iji.2017.1017a

Gunawan, I. (2017). Indonesian Curriculum 2013: Instructional Management, Obstacles Faced by Teachers in Implementation and the Way Forward. Advances in Social Science, Education and Humanities Research, 128(ICET), 5663. https://doi.org/10.2991/icet-17.2017.9

Ichsan, I. Z., Rahmayanti, H., Purwanto, A., Sigit, D. V., Singh, C. K. S., \& Babu, R. U. M. (2020). HOTS-AEP-COVID-19: Students Knowledge and Digital Worksheet of ILMIZI Environmental Learning Model. International Journal of Advanced Science and Technology, 29(6), 5231-5241.

Ichsan, I. Z., Sigit, D. V., Miarsyah, M., Ali, A., Arif, W. P., \& Prayitno, T. A. (2019). HOTS-AEP: Higher order thinking skills from elementary to master students in environmental learning. European Journal of Educational Research, 8(4), 935-942. https://doi.org/10.12973/eu-jer.8.4.935

Ichsan, I. Z., Sigit, D. V., Miarsyah, M., Ali, A., Suwandi, T., \& Titin. (2020). Implementation supplementary book of green consumerism: Improving students hots in environmental learning. European Journal of Educational Research, 9(1), 227-237. https://doi.org/10.12973/eu-jer.9.1.227

Jailani, J., Sugiman, S., \& Apino, E. (2017). Implementing the problem-based learning in order to improve the students' HOTS and characters. Jurnal Riset Pendidikan Matematika, 4(2), 247. https://doi.org/10.21831/jrpm.v4i2.17674

Kamaludin, Ngadiman, Festiawan, R., Kusuma, I. J., \& Febriani, A. R. (2020). Pengembangan Permainan Pecah Piring Sintren: Pemanfaatan Olahraga Tradisional Pada Pembelajaran untuk Meningkatkan Kemampuan Motorik Kasar Anak. TEGAR: Journal of Teaching Physical Education in Elementary SchoolJournal of Teaching Physical Education in Elementary School, 3(5), 37-45.

Kim, L. E., Jörg, V., \& Klassen, R. M. (2019). A Meta-Analysis of the Effects of Teacher Personality on Teacher Effectiveness and Burnout. Educational Psychology Review, 31(1), 163-195. https://doi.org/10.1007/s10648-018-9458-2

Kogoya, T., Mutohir, C., Pramono, M., \& Festiawan, R. (2021). Application Of Cooperative Learning Models Jigsaw Type For Improving Learning Outcomes Groundstroke Forehand Tonnis. Ann Trop Med \& Public Health, 24(3). https://doi.org/https://doi.org/10.36295/ASRO.2021.24370

Lin, T. J., Lin, T. C., Potvin, P., \& Tsai, C. C. (2019). Research trends in science education from 2013 to 2017: a systematic content analysis of publications in selected journals. International Journal of Science Education, 41(3), 367-387. https://doi.org/10.1080/09500693.2018.1550274

Narayanan, S., \& Adithan, M. (2015). Analysis Of Question Papers In 
Engineering Courses With Respect To Hots (Higher Order Thinking Skills). American Journal of Engineering Education (AJEE), 6(1), 1-10. https://doi.org/10.19030/ajee.v6i1.9247

Ngadiman, Kusuma, I. J., \& Festiawan, R. (2019). Sport Development Index Of Banyumas Regency. Jurnal Pendidikan Jasmani Dan Olahraga, 4(2), 193-197. https://doi.org/10.17509/jpjo.v4i2.19181

Nurcahyo, P. J., Festiawan, R., Yoda, I. K., Wijayanto, A., \& Gustiputungurahadi, I. (2021). Study In Banyumas District: Is The Learning Materials Of Football In School Already Oriented To High Order Thinking Skill? Ann Trop Med \& Public Health, 24(3). https://doi.org/https://doi.org/10.36295/ASRO.2021.24366

Pratama, G. S., \& Retnawati, H. (2018). Urgency of Higher Order Thinking Skills (HOTS) Content Analysis in Mathematics Textbook. Journal of Physics: Conference Series, 1097(1), 1-8. https://doi.org/10.1088/1742$6596 / 1097 / 1 / 012147$

Retnawati, H., Hadi, S., \& Nugraha, A. C. (2016). Vocational high school teachers' difficulties in implementing the assessment in curriculum 2013 in Yogyakarta Province of Indonesia. International Journal of Instruction, 9(1), 33-48. https://doi.org/10.12973/iji.2016.914a

Sugiyono. (2016). Metode penelitian kuantitatif, kualitatif, dan R\&D. Bandung: Alfabeta.

Tyas, E. H., \& Naibaho, L. (2021). Hots Learning Model Improves the Quality of Education. International Journal of Research -GRANTHAALAYAH, 9(1), 176182. https://doi.org/10.29121/granthaalayah.v9.i1.2021.3100

Van der Kleij, F. M., Cumming, J. J., \& Looney, A. (2018). Policy expectations and support for teacher formative assessment in Australian education reform. Assessment in Education: Principles, Policy and Practice, 25(6), 620-637. https://doi.org/10.1080/0969594X.2017.1374924

Wechsler, S. M., Saiz, C., Rivas, S. F., Vendramini, C. M. M., Almeida, L. S., Mundim, M. C., \& Franco, A. (2018). Creative and critical thinking: Independent or overlapping components? Thinking Skills and Creativity, 27(December 2017), 114-122. https://doi.org/10.1016/j.tsc.2017.12.003

Wicaksono, P. N., Kusuma, I. J., Festiawan, R., \& Widanita, N. (2020). Evaluasi penerapan pendekatan saintifik pada pembelajaran pendidikan jasmani materi teknik dasar passing sepak bola Evaluation of application of scientific approach in physical education learning basic technical material for football passing. Jurnal Pendidikan Jasmani Indonesia, 16(1), 41-54. https://doi.org/https://doi.org/10.21831/jpji.v16i1.29774

Widana, I. W., Suarta, I. M., \& Citrawan, I. W. (2019). Work motivation and 
creativity on teacher ability to develop HOTS-based assessments. International Journal of Social Sciences and Humanities, 3(3), 188-200.

Widiatsih, A., Wardani, D. A. R., Royhana, U., Djamali, F., \& Septory, B. J. (2020). The development of mathematical problem based on Higher Order Thinking Skill (HOTS) on comparative material by implementing PBL and its effect on the teacher's creative thinking skill. Journal of Physics: Conference Series, 1538(1), 1-11. https://doi.org/10.1088/1742-6596/1538/1/012110

Yuliati, S. R., \& Lestari, I. (2018). Higher-Order Thinking Skills (Hots) Analysis of Students in Solving Hots Question in Higher Education. Perspektif Ilmu Pendidikan, 32(2), 181-188. https://doi.org/10.21009/pip.322.10

Yustifar, A., Rachman, H. A., Festiawan, R., Yoda, I. K., \& Suwiwa, I. G. (2021). The Application Of Problem-Based Learning In Physical Educations To Improve Learning Outcomes A Game Of Volleyball Class X Sma N 1 Sleman. Ann Trop Med \& Public Health, 24(3). https://doi.org/http://doi.org/10.36295/ASRO.2021.24320 